\title{
Radioimmunoassay of Human Parathyroid Hormone in Serum
}

\author{
Claude D. Arnaud, Hang S. Tsao, and Travis Littledike with the \\ technical assistance of Judrth Hess, Karen LAAKso, and \\ JULIANNA BischofF \\ From the Department of Endocrine Research, Mayo Clinic and Mayo \\ Foundation, Rochester, Minnesota 55901 and the National Animal \\ Disease Laboratory, Ames, Iowa 50010
}

A BSTRACT A new radioimmunoassay for human parathyroid hormone (PTH) in serum, which can measure the hormone present in $94 \%$ of the normal sera tested, is described. It is based on the ability of human PTH to compete with ${ }^{12} \mathrm{I}$-labeled bovine PTH for binding to an antiserum directed against porcine PTH. This antiserum distinguishes between human PTH extracted from parathyroid adenomata and that present in hyperparathyroid sera. Evidence is given to suggest that this is due to immunochemical changes in the hormone extracted from adenomata and not to immunochemical heterogeneity of the hormone present in serum.

Physiologic data supporting the validity and specificity of the assay are presented. Induced episodes of hypercalcemia and hypocalcemia resulted in appropriate responses in serum immunoreactive PTH (IPTH) in normal subjects and in patients with Paget's disease of bone. In normals, there was a progressive increase in serum IPTH in the late afternoon and evening, suggesting a diurnal secretory rhythm. A negative correlation was found between the serum calcium and serum IPTH over the normal range of serum calcium values; a positive correlation was found between these variables in patients with primary hyperparathyroidism. There was apparent overlap between serum IPTH values in normal subjects and patients with primary hyperparathyroidism, but formal discriminate analysis of values for serum calcium and IPTH demonstrated separation of these two groups, without overlap.

\section{INTRODUCTION}

Radioimmunoassay of human parathyroid hormone (hPTH) in biologic fluids has been unusually difficult (1). Sufficient quantities of crude hPTH for antibody production or of homogeneous hPTH for use as a refer-

Received for publication 30 March 1970 and in revised form 23 June 1970. ence standard and radioiodinated preparation have not been available, the cross-reaction between bovine parathyroid hormone (bPTH) (the only species of parathyroid gland readily available in large enough quantities for extraction and purification of the hormone) and hPTH is incomplete, the concentrations of hPTH in normal serum are low, and the hPTH present in the serum of patients with hyperfunctioning parathyroid glands may be immunologically heterogeneous (2).

Except for the unique experience of Reiss and Canterbury (3) and Reiss, Canterbury, and Egdahl (4), radioimmunoassay systems for hPTH reported to date (5-7) have been barely able to measure normal serum levels of the hormone, have shown a large overlap between the values in normal and hyperparathyroid sera, and, occasionally, have been unable to detect hPTH in sera of patients with proved hyperparathyroidism.

Our experience with as many as 12 different antisera to $\mathrm{bPTH}$, raised in both guinea pigs and chickens, which cross-react with hPTH has been similarly discouraging. This led us to investigate the possibility that the crossreaction between porcine ( $\mathrm{pPTH})$ and $\mathrm{hPTH}$ might be better than that between bPTH and hPTH. Although this question cannot be answered yet, our studies have resulted in the development of an unusually sensitive radioimmunoassay for hPTH in serum, using a guinea pig anti-pPTH serum, hPTH or pPTH standard, and ${ }^{181} \mathrm{I}$ labeled bPTH antigen.

The present paper details ( $a$ ) the procedural aspects of this new radioimmunoassay for hPTH in serum, (b) an evaluation of its sensitivity and reproducibility, (c) physiologic data supporting the assay's validity, and $(d)$ our experience in using this assay to distinguish between normal and hyperparathyroid subjects.

\section{METHODS}

Production of antibodies to parathyroid hormone. Two guinea pigs were immunized at irregular intervals (2-4 wk) 
TABLE I

Stock Solutions Used in Radioimmunoassay of $h P T H$

1. Antiserum diluent: $2 \%$ control guinea pig serum in $0.1 \mathrm{M}$ sodium barbital buffer, pH 8.6, with $500 \mathrm{U} / \mathrm{ml}$ Trasylol (FBA Pharmaceuticals, Inc.).

2. Standard diluent: 1:10 human hypoparathyroid plasma in 0.1 M sodium barbital buffer, $\mathrm{pH} 8.6$, with $500 \mathrm{U} / \mathrm{ml}$ Trasylol.

3. Guinea pig anti-pPTH serum 1 diluted to $1: 15,000$ in antiserum diluent.

4. Standard PTH, all in standard diluent:

a. bPTH: $50.0,5.0$, and $0.5 \mathrm{ng} / \mathrm{ml}$.

b. pPTH : $50.0,5.0$, and $0.5 \mathrm{ng} / \mathrm{ml}$.

c. G-100 hPTH : $225,22.5$, and $2.5 \mathrm{ng} / \mathrm{ml}$.

d. Ether-precipitate-stage product of extraction of human parathyroid adenomata (ether extract, hPTH): $2,500,250$, and $25 \mathrm{ng} / \mathrm{ml}$.

e. Standard hyperparathyroid serum: undiluted, 1:10, and $1: 100$.

by subcutaneous injection (abdomen) in multiple sites with urea-trichloroacetic acid (urea-TCA) extract of dried, defatted, porcine parathyroid glands (8) dissolved in $0.01 \mathrm{M}$ acetic acid and emulsified in an equal volume of Freund's adjuvant. Antisera to bPTH were produced by the same procedure when guinea pigs were used but, in chickens, a urea-TCA extract of dried, defatted, bovine parathyroid glands $(9,10)$ emulsified in sesame oil was injected into the thigh muscles in $10-\mathrm{mg}$ doses every week. Antibodies to PTH were detected in the plasma of guinea pigs after four injections of $5 \mathrm{mg}$ (1000 USP units) per injection of these extracts and progressively increased in titer with further immunization. The antiserum to $\mathrm{pPTH}$ from guinea pig 1 was selected for routine use on the basis of its high affinity for hPTH. This antiserum has been stored at $-18^{\circ} \mathrm{C}$ for 9 months without significant loss of antibody. Antibodies to bPTH were detected in chickens after 3 months of immunization. From both guinea pigs and chickens, blood was drawn into heparinized syringes via cardiac puncture.

Standard parathyroid hormone preparations and radioiodination. bPTH was isolated by the method of Rasmussen, Sze, and Young (9) and Hawker, Glass, and Rasmussen (10). It had a biopotency of $3000 \mathrm{U} / \mathrm{mg}$ protein and essentially the same amino acid composition as reported by that group. pPTH was extracted and purified by the method of Littledike and Hawker (8); it had a biopotency of 1500 $\mathrm{U} / \mathrm{mg}$ and was contaminated to the extent of approximately $50 \%$ as assessed by disc-gel electrophoresis. hPTH was extracted $(9,10)$ from a pool of $10 \mathrm{~g}$ of dried, defatted, chief cell parathyroid adenomata removed at operations and frozen immediately after pathologic examination, no more than 2 $\mathrm{hr}$ after excision; crude extracts and a fraction from a Sephadex G-100 fractionation of the trichloroacetic acid precipitate (G-100 hPTH), which was approximately $20 \% \mathrm{hPTH}$ by disc-gel electrophoresis and immunoreactivity when compared with $\mathrm{bPTH}$, were studied. These human preparations have not yet been bioassayed because of the relatively small quantities available.

Radioiodination of bPTH and pPTH was accomplished by the Berson and Yalow modification (11) of the Hunter and Greenwood procedure (12) on the day of receipt of ${ }^{131} \mathrm{I}$ (Iso/Serv Div., Cambridge, Mass.). The labeled hormone al- ways was used in radioimmunoassays within 4 days of radioiodination.

Adsorption of bPTH- ${ }^{181} I$ to glassware. Mixtures of the same quantity of PTH- ${ }^{-10} \mathrm{I}$ in standard diluent (Table I) and a varying quantity of hypoparathyroid serum in standard diluent were added to the same test tubes which are routinely used in the assay (flint glass, $13 \times 75 \mathrm{~mm}$ ) in a total volume of $0.5 \mathrm{ml}$. After $2 \mathrm{hr}$ of incubation at $4^{\circ} \mathrm{C}$, the contents of the test tubes and a single $2-\mathrm{ml}$ wash with $0.1 \mathrm{M}$ barbital buffer, $\mathrm{pH} 8.6$, without serum were poured into counting vials. The empty test tubes and counting vials were then assayed for radioactivity.

Conditions of routine assay. A nonequilibrium system was used routinely; however, for comparison, an equilibrium system has been studied. In both systems, $0.5 \mathrm{ml}$ incubation mixtures were prepared in flint glass $13 \times 75 \mathrm{~mm}$ test tubes and consisted of $100 \mu \mathrm{l}$ of stock guinea pig 1 anti-pPTH serum (GP 1 anti-pPTH), various quantities of standard PTH solutions or unknown sera made up to $200 \mu 1$ with standard diluent, and $200 \mu 1$ of PTH- ${ }^{181} \mathrm{I}$ diluted in standard diluent to contain approximately $10,000 \mathrm{cpm}$ (Nuclear-Chicago automatic gamma scintillation system). The compositions of the standard stock solutions are shown in Table I and the general assay scheme is shown in Tables II and III. The differences between the equilibrium and the nonequilibrium system relate only to the preincubation phase and differences in antibody concentrations to which stable and ${ }^{131}$ I-labeled PTH are exposed. In the nonequilibrium system, standard and unknown stable PTH were exposed to an antiserum concentration of $1: 45,000$ during the 4 day preincubation phase, and the ${ }^{181} I$-labeled PTH and stable PTH were exposed to an antiserum concentration of 1:75,000 during the final incubation phase.

An extensive set of values are essential for accurate and precise calculation and interpretation of results. These values are correction factors which are used for two purposes: (a) to correct for incubation "damage" of ${ }^{121} \mathrm{I}$-labeled PTH,

TABLE II

General Scheme for Radioimmunoassay of hPTH

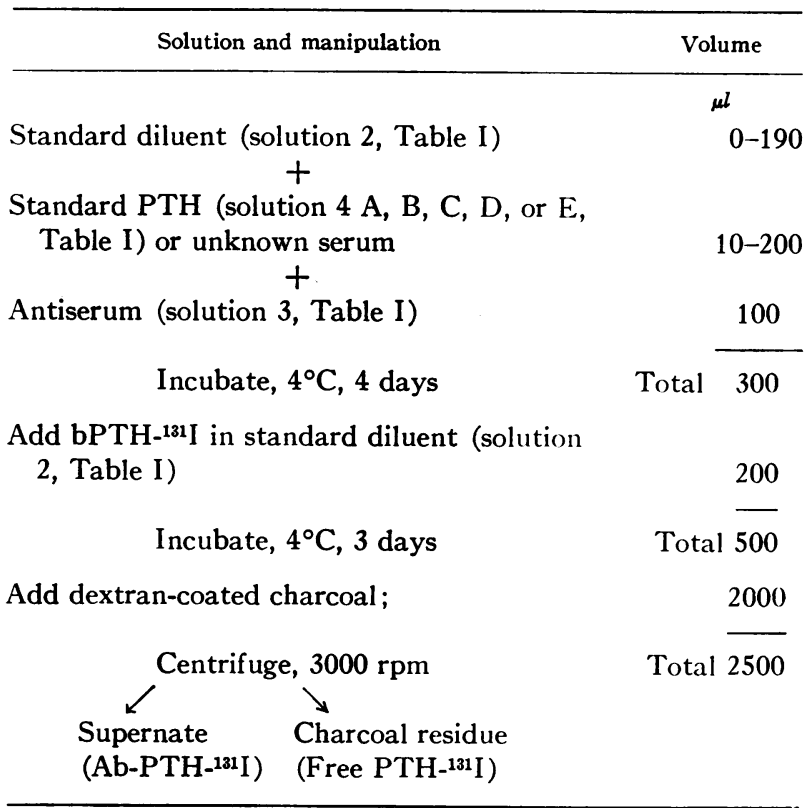


and $(b)$ to correct for nonspecific inhibition of the immune reaction by serum. As shown in Table III, a series of "control" incubations were done with varying quantities of human hypoparathyroid serum (PTX serum) and with varying quantities of individual unknown sera and bPTH- ${ }^{181} \mathrm{I}$. The percentage of the total radioactivity present as "damaged" PTH-191 I was calculated in each instance and applied to the calculation of results obtained under a matched set of conditions as described by Yalow and Berson (13). This maneuver was necessary because of the varying "damaging" qualities of individual sera and dilutions of the same serum and the varying degrees to which different preparations of PTH- ${ }^{181}$ I were susceptible to incubation "damage." Also in Table III are shown a number of "trace" incubations in which varying quantities of PTX serum were incubated with antiserum and $\mathrm{bPTH}-{ }^{181} \mathrm{I}$. The ratios of antibody-bound PTH- ${ }^{181}$ I to free PTH- ${ }^{181} \mathrm{I}$ (B/F) obtained when these quantities of PTX serum were present differed (see Results section). They were used as reference values for the $\mathrm{B} / \mathrm{F}$ ratio when no PTH was present in the immune system but when serum concentrations differed. Unknown sera were matched with tubes containing the same amount of PTX serum and a percentage was obtained by dividing the $B / F$ ratio obtained for the unknown by that obtained for PTX serum. This percentage was applied to the standard curve which was plotted as percentage values obtained by dividing the values for the $\mathrm{B} / \mathrm{F}$ ratio for a given concentration of standard $\mathrm{PTH}$ or hyperparathyroid sera by the $\mathrm{B} / \mathrm{F}$ ratio obtained for $1: 10 \mathrm{PTX}$ serum. Although this procedure does not consider the possibility that different sera may inhibit the immune reaction nonspecifically to variable extents, it is the best means we have been able to devise for correcting for this problem.

Standard curves were routinely done in duplicate, one at the beginning and one at the end of a given assa $J$. All unknown sera with adequate quantities of immunoreactive PTH were assayed in duplicate at three different dilutions, and results were acceptable only if the slopes of the curves produced were not significantly different from those obtained with the standard hyperparathyroid serum and if the mean of duplicate values at three dilutions agreed within $10 \%$. With the present radioimmunoassay system it was rare that more than two dilutions of normal serum yielded $B / F$ ratios which were significantly lower than those of control PTX serum, but these dilution-dose-response curves also, in most instances, were parallel to those obtained with standard hyperparathyroid serum. With those normal sera which yielded only one $B / F$ ratio significantly lower than that obtained with hypoparathyroid serum, we required that a twofold dilution of the sera yielded a $B / F$ ratio equal to or slightly higher than that obtained with an equal dilution of PTX serum. Rarely, normal serum produced a minimal decrease in $\mathrm{B} / \mathrm{F}$ ratio with dilution, and these sera were discarded as samples which nonspecifically interfere with the immune reaction in a manner for which we cannot correct.

Statistical analyses of all results were done by methods described by Snedecor and Cochran (14).

Diluted antisera were pipeted with $100-\mu$ l borosilicate glass micropipets, stock standard PTH solutions and standard diluent with microsyringes (Hamilton Co., Whittier, Calif.), and $\mathrm{PTH}{ }^{-181} \mathrm{I}$ with the York jet pipet (York Instrument Corp., Berkeley, Calif.). Incubation tubes were placed in a special wooden rack which accommodates 100 tubes and were capped securely with a plastic (Saran)-enclosed, spongecovered board of the same dimensions as the rack, rubber bands firmly securing the test tube-covering device to the
TABLE III

Flow Sheet for Radioimmunoassay of hPTH

\begin{tabular}{|c|c|c|c|c|}
\hline $\begin{array}{l}\text { Standard } \\
\text { serum }\end{array}$ & $\begin{array}{l}\text { Sta } \\
\text { Anti- } \\
\text { serum, } \\
\text { GP anti- } \\
\text { pPT H } 1 \text {, } \\
1: 15,000\end{array}$ & $\begin{array}{l}\text { dards } \\
\text { Standard } \\
\text { HPT } \\
\text { serum, } \\
1: 10\end{array}$ & $\begin{array}{l}\text { Standard } \\
\text { diluent }\end{array}$ & bPTH-121 I \\
\hline $\begin{array}{c}\mu l / m l \\
\text { Control } \times 6\end{array}$ & $\stackrel{\mu l}{100^{*}}$ & $\begin{array}{r}\mu l \\
0\end{array}$ & $\begin{array}{c}\mu l \\
200\end{array}$ & $\begin{array}{c}\mu l \\
200\end{array}$ \\
\hline "Trace" $\times 6$ & 100 & $\mathbf{0}$ & 200 & 200 \\
\hline 2 & 100 & 10 & 190 & 200 \\
\hline 3 & 100 & 15 & 185 & 200 \\
\hline 4 & 100 & 20 & 180 & 200 \\
\hline 5 & 100 & 25 & 175 & 200 \\
\hline 6 & 100 & 30 & 170 & 200 \\
\hline 8 & 100 & 40 & 160 & 200 \\
\hline 10 & 100 & 50 & 150 & 200 \\
\hline 12 & 100 & 60 & 140 & 200 \\
\hline 14 & 100 & 70 & 130 & 200 \\
\hline 16 & 100 & 80 & 120 & 200 \\
\hline 18 & 100 & 90 & 110 & 200 \\
\hline 20 & 100 & 100 & 100 & 200 \\
\hline 24 & 100 & 120 & 80 & 200 \\
\hline
\end{tabular}

\begin{tabular}{|c|c|c|c|c|}
\hline \multirow[b]{2}{*}{ Sample } & \multicolumn{2}{|c|}{ Unknown } & \multirow[b]{2}{*}{$\begin{array}{c}\text { Human } \\
\text { hypopara- } \\
\text { thyroid } \\
\text { serum (A) } \\
\text { or standard } \\
\text { diluent (B) }\end{array}$} & \multirow[b]{2}{*}{ bPTH-131 I } \\
\hline & $\begin{array}{l}\text { Anti- } \\
\text { serum, } \\
\text { GP anti- } \\
\text { pPTH } 1 \text {, } \\
1: 15,000\end{array}$ & $\begin{array}{l}\text { Unknown } \\
\text { serum }\end{array}$ & & \\
\hline & $\mu l$ & $\mu l$ & $\mu l$ & $\mu l$ \\
\hline Control $\times 6$ & 0 & 0 & $200(\mathrm{~A})$ & 200 \\
\hline Control $\times 6$ & $\mathbf{0}$ & 0 & $100(\mathrm{~A})$ & 200 \\
\hline Control $\times 1$ & $100 *$ & 200 & 0 & 200 \\
\hline Control $\times 1$ & $100 *$ & 100 & $100(B)$ & 200 \\
\hline Control $\times 1$ & $100 *$ & 50 & 150 (B) & 200 \\
\hline Control $\times 1$ & $100^{*}$ & 20 & $180(B)$ & 200 \\
\hline "Trace" $\times 6$ & 100 & 0 & 200 (A) & 200 \\
\hline "Trace" $\times 6$ & 100 & $\mathbf{0}$ & $100(\mathrm{~A})$ & 200 \\
\hline Unknown $\times 2$ & 100 & 200 & 0 & 200 \\
\hline Unknown $\times 2$ & 100 & 100 & 100 (B) & 200 \\
\hline Unknown $\times 2$ & 100 & 50 & 150 (B) & 200 \\
\hline Unknown $\times 2$ & 100 & 20 & 180 (B) & 200 \\
\hline Unknown $\ddagger \times 2$ & 100 & 200 & 0 & 200 \\
\hline Unknown $\ddagger \times 2$ & 100 & 100 & 100 (B) & 200 \\
\hline Unknown $\ddagger \times 2$ & 100 & 50 & 150 (B) & 200 \\
\hline Unknown $\neq \times 2$ & 100 & 20 & 180 (B) & 200 \\
\hline
\end{tabular}

* Diluent (solution 1, Table I) only.

‡ Diluted 1:10 with standard diluent, solution 2, Table I.

test tube rack (diagram of rack and covering device supplied on request). Whole racks were incubated in a conventional refrigerator, the interior temperature of which was monitored and maintained at $4^{\circ} \mathrm{C}$

Separation of antibody-bound PTH-1"I from "free" $P T H$ ${ }^{131} I$. A modification of the dextran-coated charcoal method of Herbert, Lau, Gottlieb, and Bleicher (15) was used. $200 \mathrm{ml}$ of cold $\left(4^{\circ} \mathrm{C}\right)$ buffer (15) was added, with mixing, to each of two beakers containing $10 \mathrm{~g}$ of Norit A charcoal and 1.0 $\mathrm{g}$ of dextran 70 (Pharmacia Fine Chemicals, Inc., Piscataway, N. J.). After a homogeneous suspension of charcoal and dextran was obtained, the contents of both beakers were mixed (magnet stirrer) in a third beaker overnight at $4^{\circ} \mathrm{C}$. The suspension then was centrifuged at $1000 \mathrm{~g}$ (Sorvall 


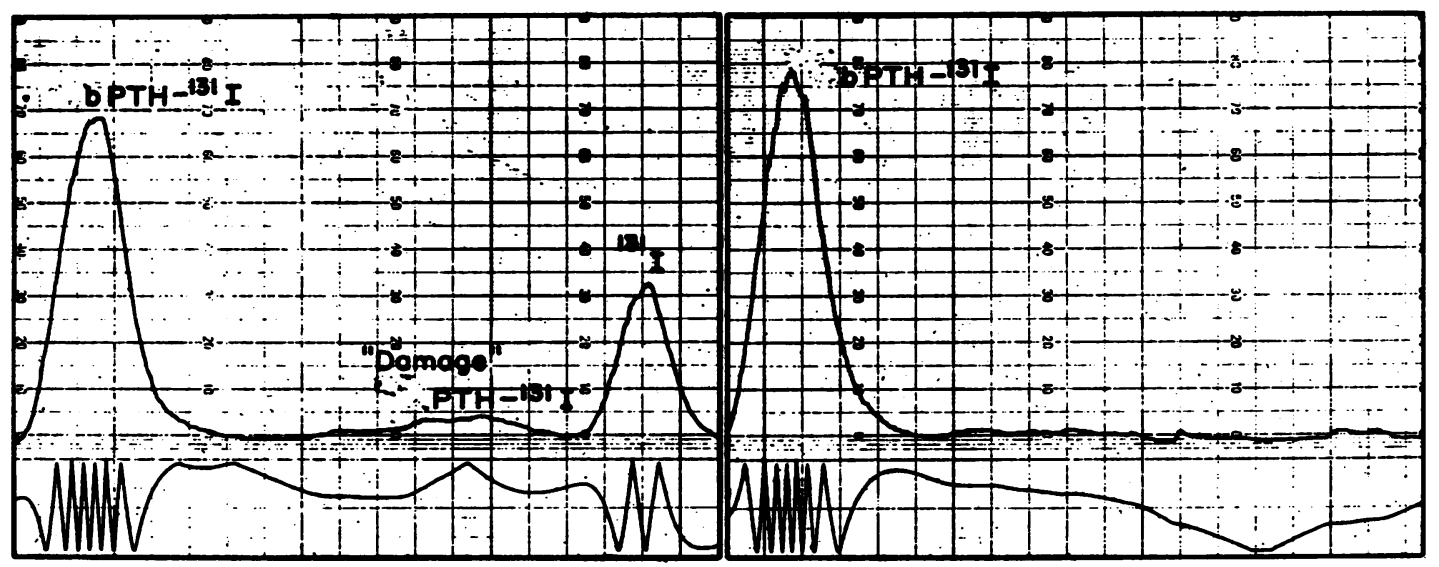

FIGURE 1 Chromatoelectrophoretograms of bPTH iodination mixture before (left) and after (right) purification by cellulose chromatography.

TABLE IV

bPTH-131 I Binding to Excess Antibody*

\begin{tabular}{ccc}
\hline Antiserum & Binding & “Damage" $\ddagger$ \\
\hline & $\%$ & $\%$ \\
GP 1 anti-pPTH, 1:100 & $91 \pm 4$ & $9.2 \pm 0.7$ \\
GP C3 anti-bPTH, 1:100 & $89 \pm 3$ & $9.5 \pm 0.6$ \\
Ch 1 12 anti-bPTH, 1:100 & $92 \pm 4$ & $9.3 \pm 0.6$ \\
\hline
\end{tabular}

* Mean $\pm 2 \mathrm{SD}, \mathrm{n}=10 ; 4$ day incubation at $4^{\circ} \mathrm{C}$.

$\ddagger$ No human serum present in incubation mixtures.

\$ Chicken.

Model RC2B refrigerated centrifuge) for $10 \mathrm{~min}$ and the supernate was decanted carefully and discarded. The dextran-coated charcoal residue was resuspended in $400 \mathrm{ml}$ of fresh buffer (15) containing human albumin $(1 \mathrm{mg} / \mathrm{ml})$ but no dextran and magnetically mixed at $4^{\circ} \mathrm{C}$ for $2 \mathrm{hr}$. While the suspension was being stirred, $2-\mathrm{ml}$ portions were removed with a graduated $10-\mathrm{ml}$ pipet and added to each incubation mixture in one rack of 100 incubation tubes at a time. After vortex mixing, the tubes were centrifuged immediately in a Sorvall nonrefrigerated centrifuge at $1200 \mathrm{~g}$. After centrifugation, the supernates were decanted carefully into new $13 \times 75 \mathrm{~mm}$ flint glass test tubes; these tubes and the centrifuge tubes containing the dextran-coated charcoal residues were placed into plastic counting tubes and were counted (automatic Nuclear-Chicago gamma counter) for a sufficient time to collect at least 10,000 counts for each tube. When chromatoelectrophoresis was used, the method of Yalow and Berson (13) was followed except that it was done at room temperature. All paper strips (Whatman 3MC) were counted twice (Packard Autogamma strip counter). At least 3000 , and usually more, counts were accumulated for each peak of radioactivity. Quantitation of areas under peaks was done with a disk integrator.

Patient studies. All sera were obtained between 7:30 and 8:00 a.m. unless otherwise indicated. Sera from normal subjects for demonstration of diurnal changes in immunoreactive hPTH were obtained during other studies of calcium metabolism while the subjects were hospitalized and ingesting

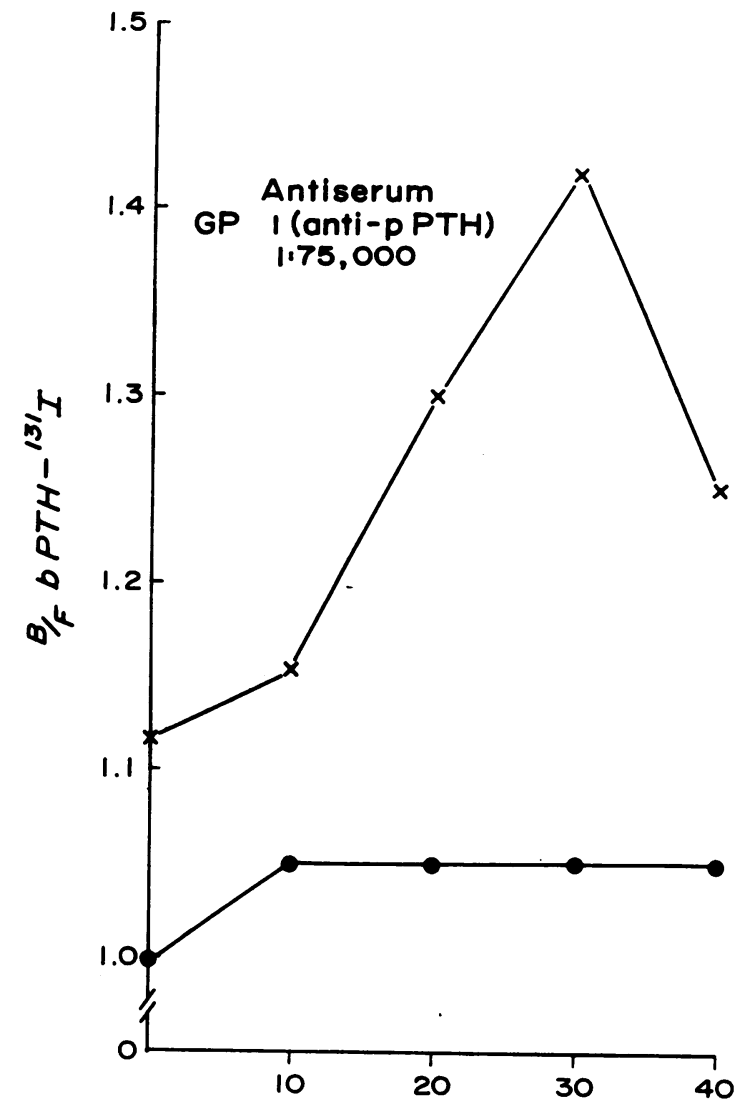

Per cent serum, added at end of incubation

FIGURE 2 Ratio of antibody bound to free bPTH-181 as function of increasing quantities of hypoparathyroid serum added to incubation mixtures immediately before chromatoelectrophoresis $(\mathrm{X}-\mathrm{X})$ or addition of dextran-coated charcoal (๑). Antiserum $=$ GP 1 anti-pPTH, 1: 75,000 . 
constant diets providing $690 \mathrm{mg}$ of calcium and $1020 \mathrm{mg}$ of phosphorus per day with no gelatin-containing foods. Studies of PTH responses to induced hypocalcemia and hypercalcemia were done under the same conditions. Hypocalcemia was induced in patients with Paget's disease of bone by the intravenous injection of $1.0 \mathrm{mg}$ of homogeneous porcine calcitonin (16); hypercalcemia was induced in normal subjects by the infusion of calcium gluconate $(15 \mathrm{mg}$ $\mathrm{Ca} / \mathrm{kg}$ ) in $5 \%$ glucose and water over a period of $4 \mathrm{hr}$.

\section{RESULTS}

Radioiodination of bovine parathyroid hormone. Although we have radioiodinated $\mathrm{pPTH}$, the estimated specific radioactivity of all preparations has been lower than that achieved with bPTH (pPTH, $50-150 \mathrm{mCi} / \mathrm{mg}$; bPTH, $200-500 \mathrm{mCi} / \mathrm{mg}$ ). Whether this observation is a true reflection of inherent molecular differences between bPTH and PPTH cannot be stated because the preparation of $\mathrm{pPTH}$ we presently have is contaminated to the extent of $50 \%$. These considerations have forced us to use labeled bPTH in the radioimmunoassay of hPTH.

The specific radioactivity of preparations of bPTH $-{ }^{121} \mathrm{I}$ varied from week to week and generally correlated directly with isotopic abundance values of the $\mathrm{I}$ received, as determined by the method of Berson and Yalow (11). Fig. 1 shows chromatoelectrophoretogram tracings of iodination mixtures before and after purification on a small cellulose column (11). Less than $4 \%$ of the purified preparation was present as "damaged" peptide and no increase in this fraction was observed during 4 days of storage at $-15^{\circ} \mathrm{C}$.

Table IV shows the mean percentage binding of PTH${ }^{181}$ I with an excess of three different antisera as assessed

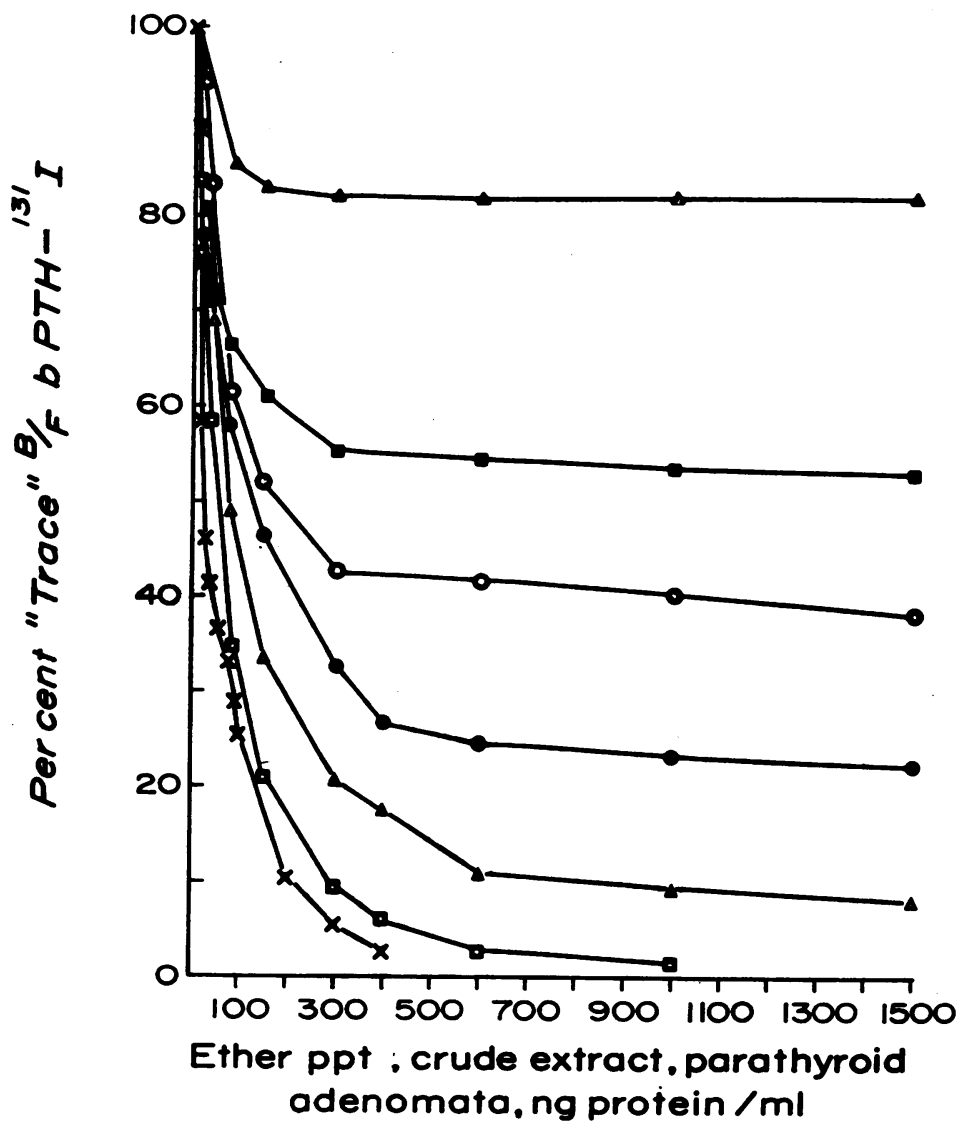

FIGURE 3 ' Standard curves: inhibition of binding of bPTH- ${ }^{2} \mathrm{I}$ to antisera against pPTH and bPTH (produced in guinea pigs and chickens) by crude extract of pooled parathyroid adenomata. All antisera were used in dilutions which resulted in $\mathrm{B} / \mathrm{F}$ ratio of $0.6-1.0$ with $\mathrm{bPTH}-{ }^{281} \mathrm{I}$ in absence of unlabeled hormone. Chicken 15 anti-bPTH, 1:2,400, $\Delta-\Delta$; guinea pig $\mathrm{C17}$ anti-bPTH, 1:20,000, $\square-\square$; chicken 5 anti-bPTH, 1:9,000, $\bigcirc-O$; guinea pig C3 anti-bPTH, 1:30,000, -1 chicken 12 anti-bPTH, $1: 2,200, \triangle-\triangle$; chicken 14 antibPTH, $1: 3,000, \square-\square$; guinea pig 1 anti-pPTH, $1: 75,000, \mathrm{X}-\mathrm{X}$. 
by chromatoelectrophoresis of incubation ( 4 days, $4^{\circ} \mathrm{C}$ ) mixtures. The mean values for the "damaged" component also are shown. It is difficult to assess the iodinated material that apparently did not bind to antibody in this experiment because trailing was observed in all of the chromatograms and some of the material measured as free PTH- ${ }^{281} \mathrm{I}$ actually may have been bound to antibody. We consider that $90 \%$ binding under these conditions is satisfactory, compared to the results of others (17).

Under the conditions of the routine assay (10\% hypoparathyroid serum), the quantity of $\mathrm{bPTH}-{ }^{181} \mathrm{I}$ which adsorbs to test tubes is low $(6.19 \pm 0.35 \%)$ and the difference between the amounts adsorbed in the presence of the lowest $(10 \%)$ and highest $(40 \%)$ concentrations of serum used in the assay is small $(1.89 \%)$. Since most assays of hyperparathyroid serum are done at serum concentrations between $10 \%$ and $20 \%$, the difference in $\mathrm{bPTH}-{ }^{121} \mathrm{I}$ adsorption is only $0.45 \%$.

Incubation, in concentrations of serum as high as $40 \%$, of the $\mathrm{bPTH}-{ }^{121} \mathrm{I}$ obtained from 50 separate iodination procedures has never resulted in levels of "damage" greater than $15 \%$ as assessed by the dextran-coated charcoal procedure. The mean percentage damage in
1000 separate incubations of these 50 preparations in varying quantities of serum for 3 days at $4^{\circ} \mathrm{C}$ was 11.65 $\pm 0.73 \%$ ( $2 \mathrm{sD}$ ).

Comparison of dextran-coated charcoal and chromatoelectrophoretic methods for separating antibody-bound and free $b P T H{ }_{-}{ }^{131} I$. The dextran-coated charcoal method is more rapid, less tedious, and uses all of the radioactivity in the incubation mixture rather than just a portion as is true with the chromatoelectrophoretic method. It is not unusual for us to process as many as 600-800 incubation mixtures per day by the dextrancoated charcoal method. However, experience has shown that, in the PTH radioimmunoassay, the modifications of the Herbert (15) procedure (noted in the Methods section) are essential to good results. For example, if the dextran-containing buffer is not replaced with buffer not containing dextran, approximately $20 \%$ of ${ }^{181} \mathrm{I}$-labeled PTH remains in the supernate as assessed by chromatoelectrophoresis. If the dextran-coated charcoal suspension is stored, used, or prepared at room temperature or if higher centrifuge speeds are used during the removal of the dextran-containing supernate than during centrifugation of the incubation mixtures after

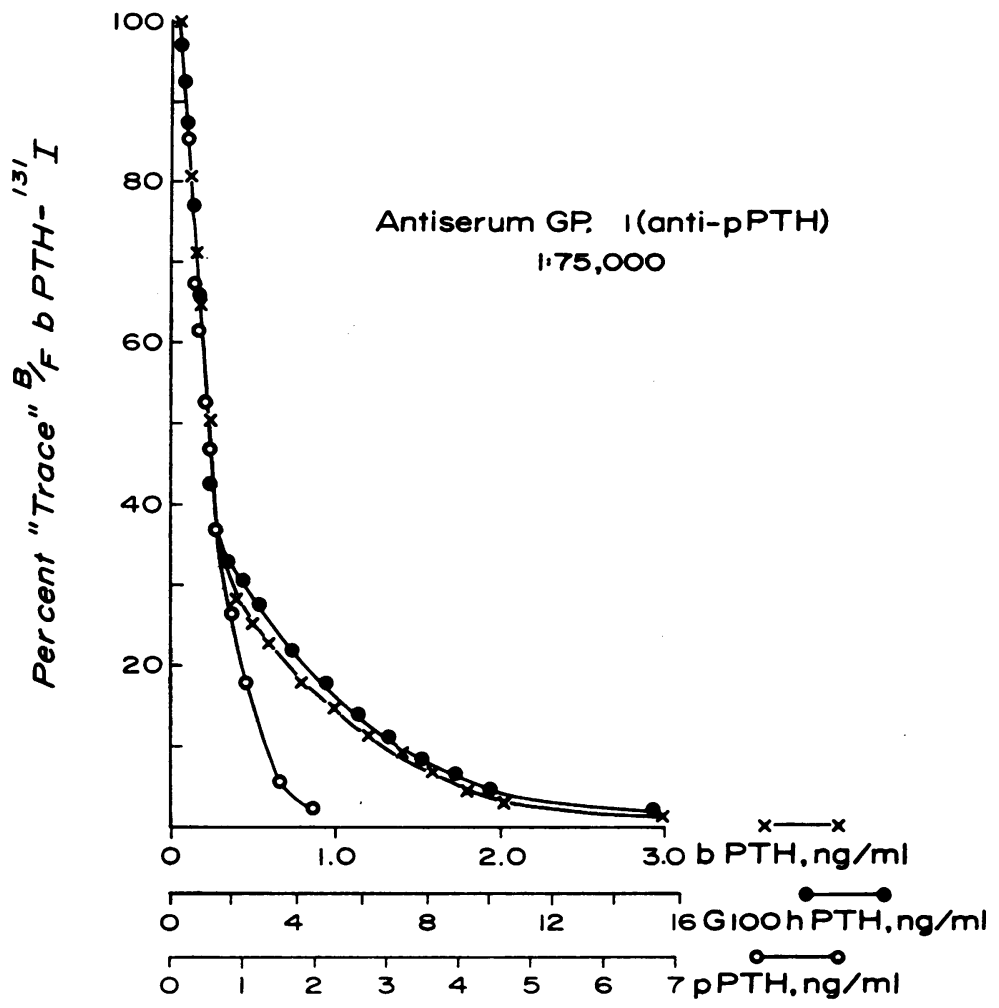

FIGURe 4 Standard curves: inhibition of binding of bPTH-281 to GP 1 anti-pPTH $(1: 75,000)$ by bPTH, purified pPTH (approximately $50 \%$ PTH), and G-100 hPTH (approximately 20\% PTH). 
addition of the dextran-coated charcoal, fines will remain in the supernate.

Under the conditions we used, $90 \%$ or more of the unbound $\mathrm{bPTH}-{ }^{18 \mathrm{I}} \mathrm{I}$ was adsorbed to dextran-coated charcoal even with 10 times the quantity of bPTH- ${ }^{10} \mathrm{I}$ routinely used. When serum concentrations of $10-40 \%$ are present with no antibody, $95 \%$ of free ${ }^{1 \mathrm{si}} \mathrm{I}$ remains in the supernate; when excess antibody is present, less than $12 \%$ of the $\mathrm{bPTH}^{-18 \mathrm{I}} \mathrm{I}$ is bound to dextran-coated charcoal.

Fig. 2 compares the results of chromatoelectrophoretic and dextran-coated charcoal methods for separation of free and antibody-bound $\mathrm{bPTH}-{ }^{281} \mathrm{I}$ under conditions similar to those used in our routine radioimmunoassay

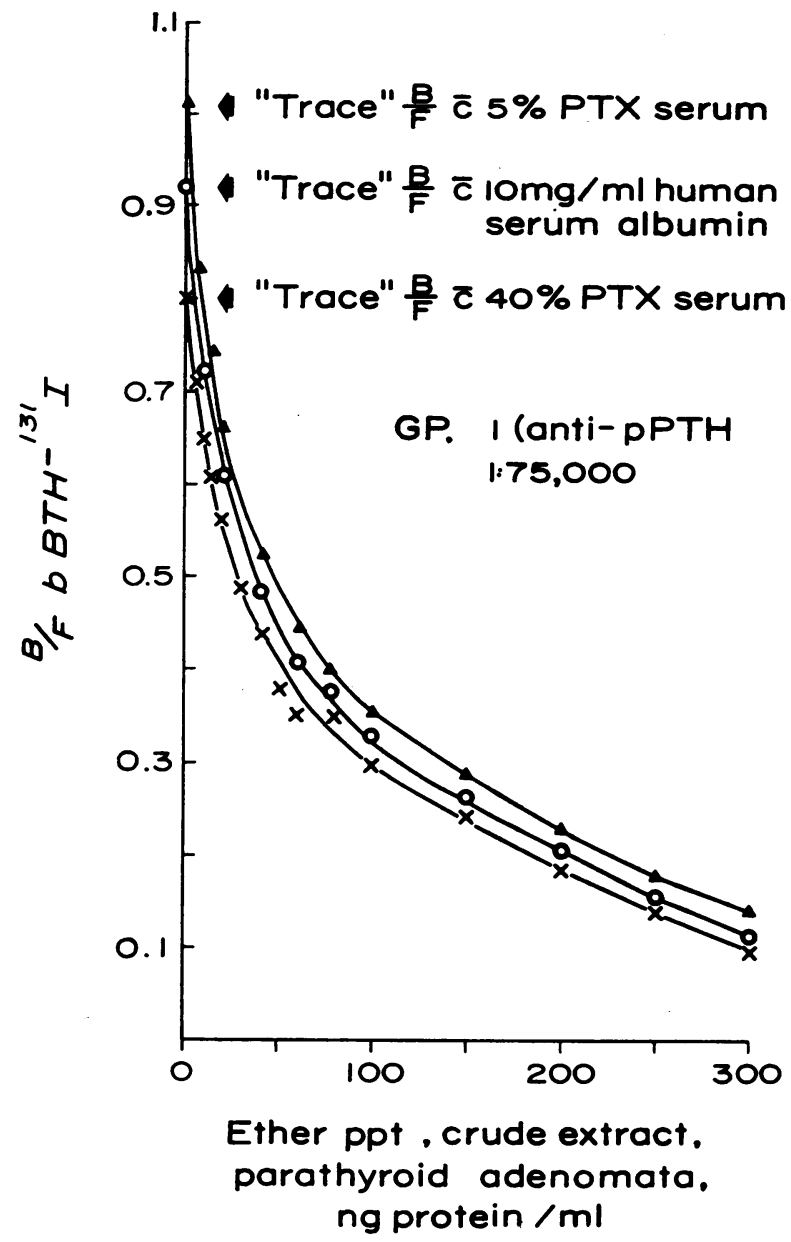

FIGURE 5 Inhibition of binding of bPTH- ${ }^{101} \mathrm{I}$ to GP 1 antipPTH by $40 \%$ hypoparathyroid serum $(\mathrm{X}-\mathrm{X})$, and human serum albumin, $10 \mathrm{mg} / \mathrm{ml}(\mathrm{O}-\mathrm{O})$, and $5 \%$ hypoparathyroid serum ( $\Delta-\Delta$ ). If values for $B / F$ are plotted as percentage of $B / F$ value obtained by incubating bPTH- ${ }^{181} \mathrm{I}$ with antiserum but without unlabeled hPTH under the same conditions ("trace" $\mathrm{B} / \mathrm{F}$ ), the resulting curves are superimposable.

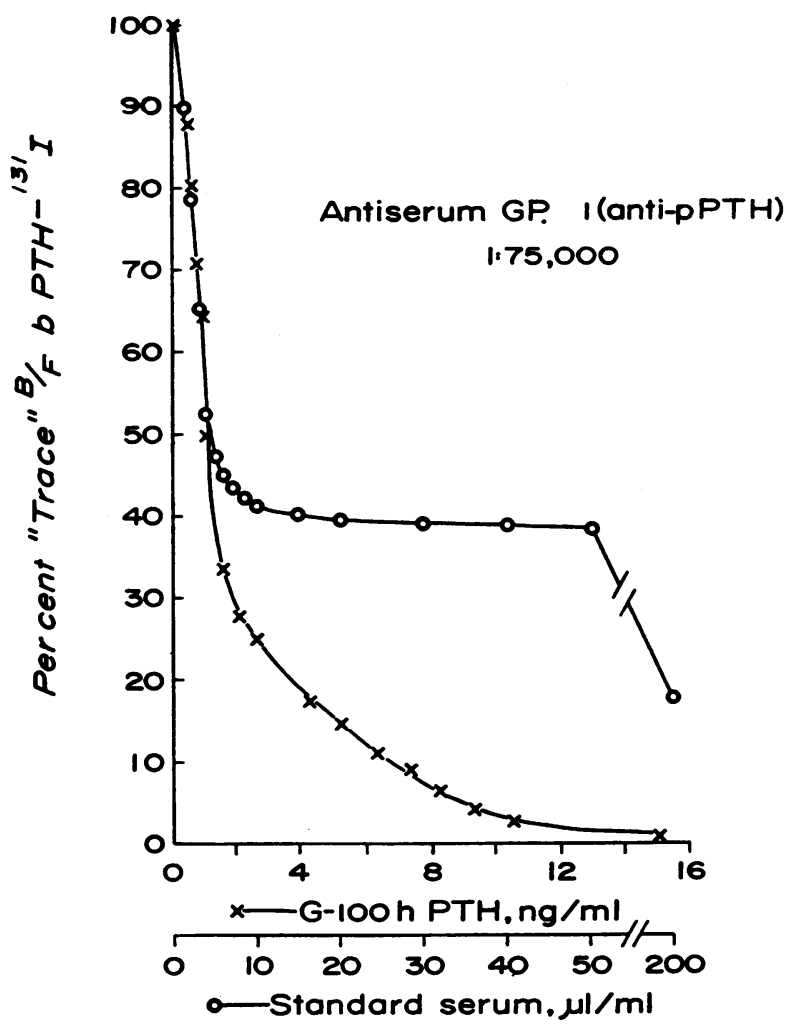

FIGURE 6 Inhibition of binding of bPTH-181 to GP 1 anti-pPTH by G-100 hPTH added to hypoparathyroid serum before addition to immune system $(\mathrm{X}-\mathrm{X})$ and standard hyperparathyroid serum $(\mathrm{O}-\mathrm{O})$. All incubations contained 1:10 hypoparathyroid serum and were identical in all respects except for unlabeled antigen.

of $\mathrm{hPTH}$ in serum. Incubations were carried out for 3 days with a final antiserum (GP 1 anti-pPTH) concentration of $1: 75,000$. Varying quantities of hypoparathyroid serum were added immediately before the separation so that the nonspecific effects of serum could be assessed. With the dextran-coated charcoal method, the ratio of radioactivity present in the supernate to that in the charcoal residue, corrected for "damage" (percentage of radioactivity present in supernate of incubation of bPTH- ${ }^{131}$ I without antiserum), increased slightly in the presence of $10 \%$ serum but remained the same with further increases to a serum concentration of $40 \%$. However, with the chromatoelectrophoretic method, the ratio progressively increased with increases in serum concentration to $30 \%$ and then decreased at $40 \%$. This is difficult to explain unless the latter system, as we use it, does not accurately assess free, antibody-bound, and "damaged" bPTH ${ }^{121} \mathrm{I}$ in the presence of relatively large concentrations of serum. The phenomenon could be explained by the failure of some of the free bPTH- ${ }^{211} I$ to 


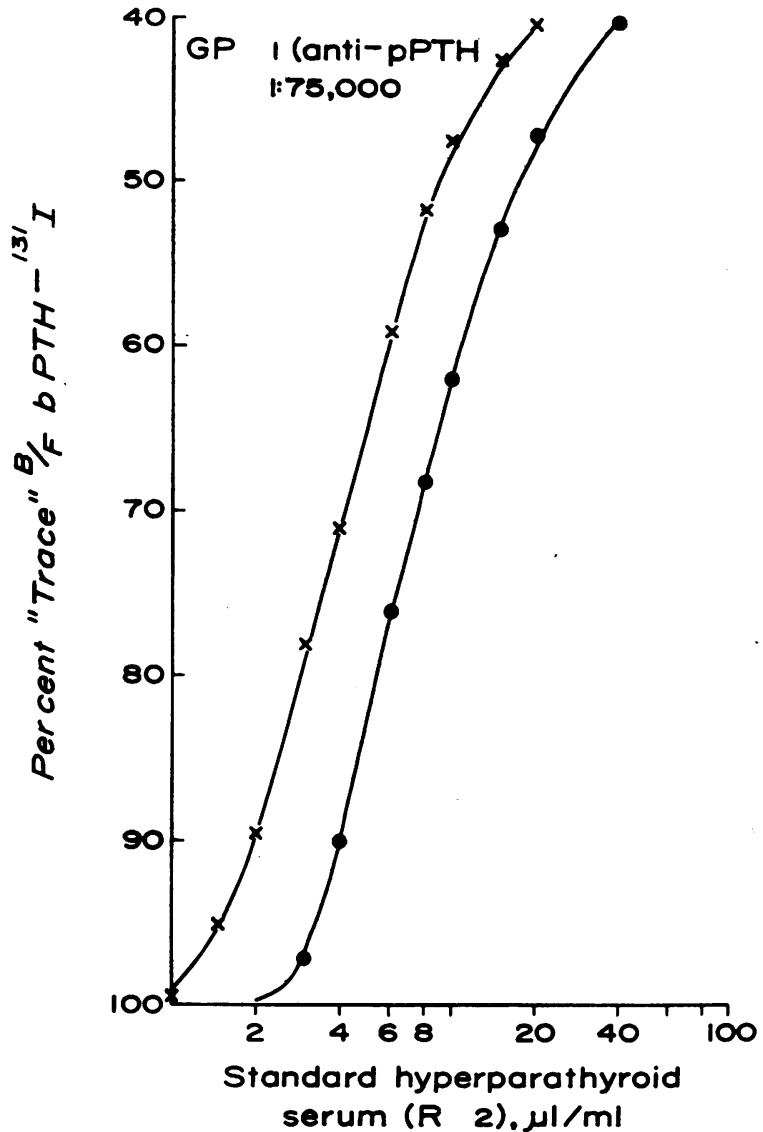

FIGURE 7 Inhibition of binding of bPTH-1 to GP 1 anti-pPTH, $1: 75,000$, by standard hyperparathyroid serum ( $R$ 2) in equilibrium system (๑- ) and nonequilibrium system ( $\mathrm{X}-\mathrm{X}$ ) (see Methods for procedures used).

adsorb to the paper strip in the presence of relatively large amounts of serum.

Antisera to parathyroid hormone. Fig. 3 shows the standard curves obtained with a variety of antisera to $\mathrm{bPTH}$ produced in chickens and guinea pigs and a single antiserum to $\mathrm{pPTH}$ produced in a guinea pig (GP 1 anti-pPTH); bPTH- ${ }^{121} \mathrm{I}$ was the labeled species and a crude extract of human parathyroid adenomata was the unlabeled species. GP 1 anti-pPTH yielded the sharpest initial slope; however, the curve obtained using chicken 14 anti-bPTH (newly developed) was quite similar. This latter antiserum was obtained from a chicken which is alive at this writing, and the antiserum is being studied with respect to its suitability for the radioimmunoassay of PTH in human serum.

A comparison of the inhibition of antibody binding of bPTH ${ }^{181}$ I to GP 1 anti-pPTH by homogeneous bPTH, G-100 hPTH, and our preparation of $50 \%$ purified pPTH is shown in Fig. 4. In this plot, all three curves can be superimposed over their initial steep portions, but the curves obtained with $\mathrm{bPTH}$ and $\mathrm{hPTH}$ deviate from the one obtained with $\mathrm{pPTH}$ at per cent of "trace" $\mathrm{B} / \mathrm{F}$ bPTH- ${ }^{23} \mathrm{I}$ values below $35 \%$. The bPTH and hPTH curves are almost superimposable over the whole range, and as little as $500 \mathrm{pg} / \mathrm{ml}$ of G-100 hPTH and $100 \mathrm{pg} / \mathrm{ml}$ of bPTH can be detected. If the bPTH used in our experiments was homogeneous and our estimate of the purity of the G-100 hPTH was correct $(20 \%)$, it appears that this immunoassay system does not distinguish well between these species and suggests that its limit of detection for $\mathrm{hPTH}$ is in the range of $0.1-0.2 \mathrm{ng} / \mathrm{ml}$.

Two important and interesting problems became apparent when we studied hypoparathyroid and hyperparathyroid sera in the immunoassay system using GP 1 anti-pPTH as antiserum. Hypoparathyroid sera (10 samples) or protein solution (human serum albumin) inhibited the binding of $\mathrm{bPTH}-{ }^{181} \mathrm{I}$ to the antibody (Fig. 5). This inhibition was not influenced by the addition of $0.18 \% \mathrm{NaCl}$ to the incubation mixtures. We assume that this inhibition is due not to hPTH but to nonspecific inhibitory effects of serum proteins and possibly other factors on the immune reaction. The means we used to deal with this problem in the immunoassay of hPTH in serum are detailed in Methods.

The second problem is illustrated by Fig. 6 . The antiserum, GP 1 anti-pPTH, distinguished clearly between the $\mathrm{hPTH}$ present in hyperparathyroid serum and that extracted and purified from parathyroid adenomata. This is not a unique observation. Berson and Yalow (2) reported similar immunologic differences detected by one of their antisera to bPTH (C329). We have taken great care to make certain that this observation is not an artifact of technique. The same result was obtained when incubations were carried out at various ionic strengths, at various $\mathrm{pH}$ values between 7.4 and 8.8 , and, as shown in Fig. 6, when G-100 hPTH was added to hypoparathyroid serum prior to its addition to the immunoassay system.

Because of the differences between standard curves obtained with G-100 hPTH and hyperparathyroid serum, with GP 1 anti-pPTH as antiserum, we have considered it necessary to use endogenous hPTH present in serum as a standard in the radioimmunoassay of sera containing unknown concentrations of $\mathrm{hPTH}$. This standard serum ( $R$ 2) was obtained from a patient with parathyroid cancer. Routinely, we plotted the standard curves obtained with this serum as a log function of the concentration of serum added to incubation mixtures because the results were more nearly linear and the reading of unknown values from the curve was less tedious. Typical curves obtained in equilibrium and nonequilibrium systems are shown in Fig. 7. The curves are similar except that the nonequilibrium system is approximately twice as sensitive as the equilibrium system. 
Standard curves prepared as a part of all immunoassays of sera reported in the present paper had essentially the same slopes and sensitivities. Unknown sera were always added in dilutions which yielded percentage of "trace" values which fell on the standard curve between 50 and $85 \%$. Standard curves produced, in this system, by a variety of hyperparathyroid sera (primary hyperparathyroidism with and without renal failure, secondary hyperparathyroidism due to renal failure and malabsorption, parathyroid cancer, and tertiary hyperparathyroidism) and sera obtained 6 months after successful renal transplantation could be superimposed (Fig. 8).

Reproducibility. In general, duplicate determinations at the same dilution of sera were in excellent agreement but, because of the occasional observation that appropriate changes in the $\mathrm{B} / \mathrm{F}$ ratio did not occur on dilution of certain sera, we studied all sera in multiple dilutions as well. The mean percentage variation of the means of duplicate determinations of hPTH in 205 different sera assayed at two dilutions (usually two- to fourfold difference in serum dilution) in 10 consecutive assays was $11.8 \pm 0.6 \%$ (SE). This represents the intra-assay variability and is comparable to that reported by Berson and Yalow (18) for the measurement of ACTH in serum. The mean percentage variation of the means of duplicate determinations of $\mathrm{hPTH}$ in 60 sera assayed at two dilutions in three pairs of assays (20 sera in each pair) was $12.2 \pm 0.8 \%$ (SE). This represents the interassay variation. All of the values for hPTH concentration in sera reported in this paper represent the means of at least duplicate determinations in two different assays.

Diurnal variations and responses of serum immunoreactive parathyroid hormone to induced hypercalcemia and hypocalcemia. When serum IPTH in five normal subjects was measured throughout the day (Fig. 9), there was a consistent, progressive increase after 12:00 noon until the last measurement, at 8 p.m., which was twice that at 8 a.m. These values correlated positively with urinary hydroxyproline excretion and phosphate clearance (data to be published separately).

Serum IPTH decreased rapidly to undetectable levels within $2 \mathrm{hr}$ of the start of a routine $4 \mathrm{hr}$ diagnostic calcium infusion in four normal subjects; it returned to normal levels with normocalcemia (Fig. 10).

In four subjects with extensive Paget's disease of bone, hypocalcemia resulted in increases in serum IPTH (Fig. 11). Responses varied qualitatively, two showing an early peak increase in serum IPTH followed by a lower sustained increase, and two showing a slow progressive increase. Serum calcium concentrations were significantly higher $(P<0.01)$ than control at $24 \mathrm{hr}$ after calcitonin administration, and IPTH measured in the same serum sample was appropriately lower than control $(P<0.01)$. The pattern of these changes in serum

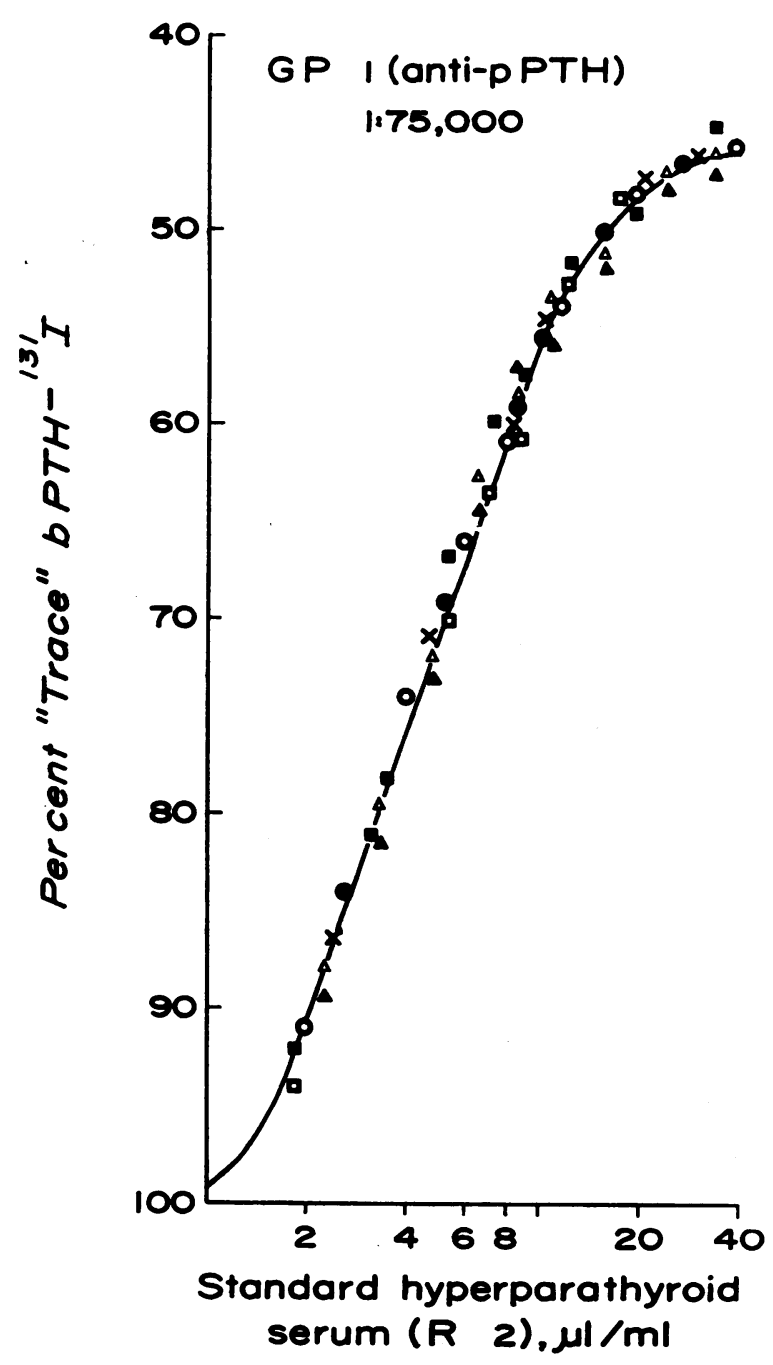

FIGURE 8 Inhibition of binding of bPTH-1m to GP 1 anti-pPTH by various hyperparathyroid sera. Curves produced by serum dilutions of each are superimposed on that of standard hyperparathyroid serum ( $R$ 2) (parathyroid cancer) (O-O). Primary hyperparathyroidism without renal failure, $\mathrm{X}-\mathrm{X}$; primary hyperparathyroidism with renal failure, $1-\mathbf{a}$; secondary hyperparathyroidism due to renal failure, $\Delta \longrightarrow \Delta$; secondary hyperparathyroidism due to malabsorption, - ; sera obtained 6 months after successful renal transplantation, $\square-\square$.

IPTH did not resemble the pattern of diurnal changes observed in the same patients the day before calcitonin administration.

Serum immunoreactive parathyroid hormone in normal, hypocalcemic, hypoparathyroid, and hyperparathyroid subjects. Our general experience in measuring IPTH in human serum is summarized in Fig. 12. Serum IPTH was undetectable in 10 patients with surgical hypoparathyroidism. All normal sera were obtained from persons who were healthy according to complete physi- 


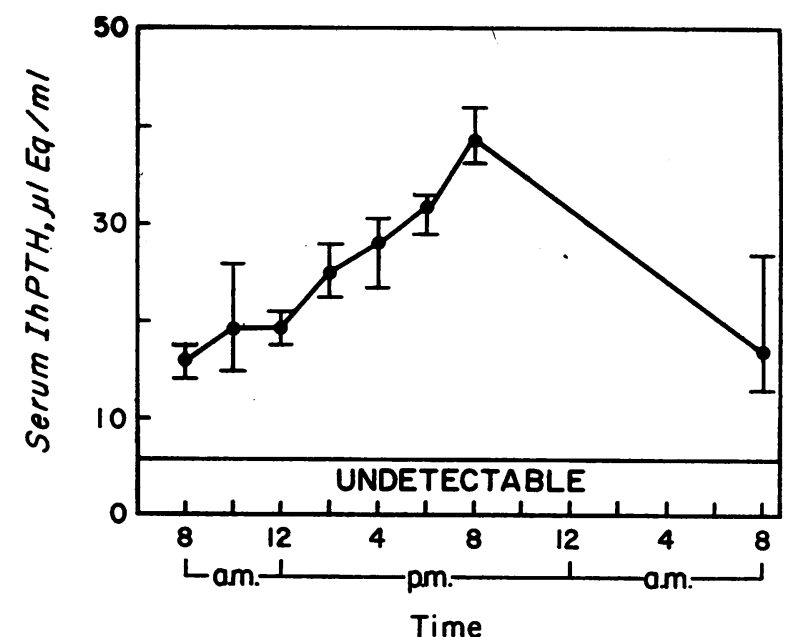

FIGURE 9 Serum IPTH in five normal subjects at different times of day. Each point on plot represents mean of triplicate determinations in all subjects. Vertical bars represent ranges.

cal examinations. They ranged in age from 13 to $76 \mathrm{yr}$ with an equal distribution between males and females. In this small sample ( 51 subjects), serum IPTH did not

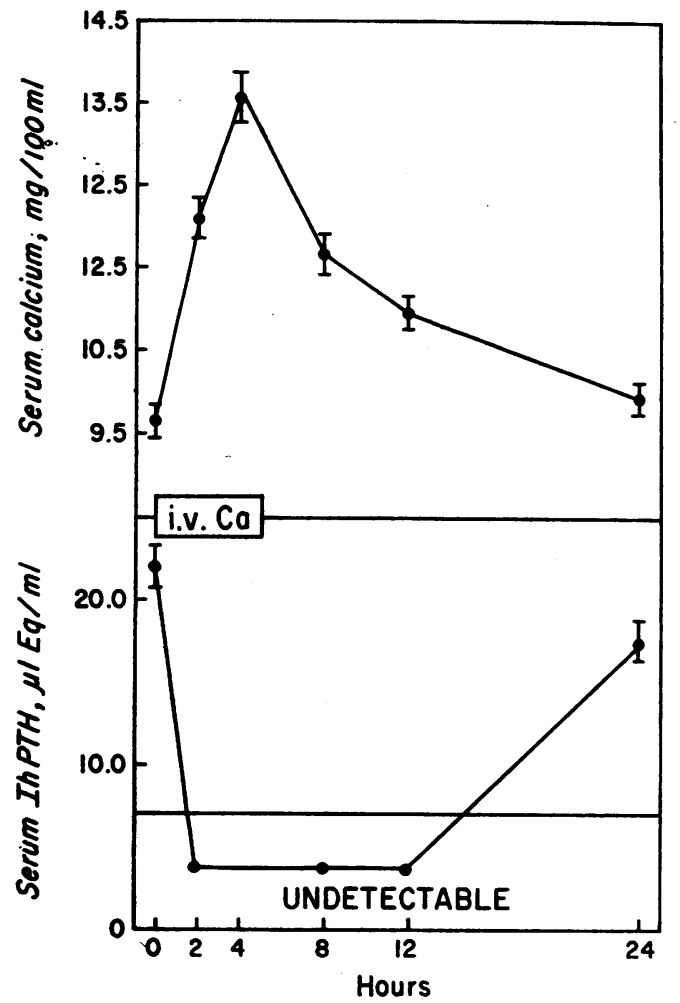

FIGURE 10 Serum IPTH in four normal subjects during hypercalcemia induced by a $4 \mathrm{hr}$ calcium infusion. Each point represents mean of triplicate determinations in all subjects. Vertical bars represent 2 sD.

C. D. Arnaud, H. S. Tsao, and T. Littledike differ significantly with age or sex, was measurable in $94 \%$ of sera studied, and ranged between undetectable and $38 \mu \mathrm{Eg} / \mathrm{ml}$. In the group with surgically proved parathyroid tumors (54 patients, all with chief cell adenoma or "adenomatous hyperplasia" [19]), serum IPTH ranged from 25 to $6500 \mu \mathrm{lEq} / \mathrm{ml}$ and there was a significant correlation between serum IPTH and the weight of the tumor. In patients suspected of having hyperparathyroidism, serum IPTH ranged from 22 to $430 \mu \mathrm{E} \mathrm{Eq} / \mathrm{ml}$. Although the hormone was measured easily in all of these sera, values for serum IPTH were within the normal range in $22 \%$ of patients with proved primary hyperparathyroidism and $49 \%$ of those with suspected hyperparathyroidism.

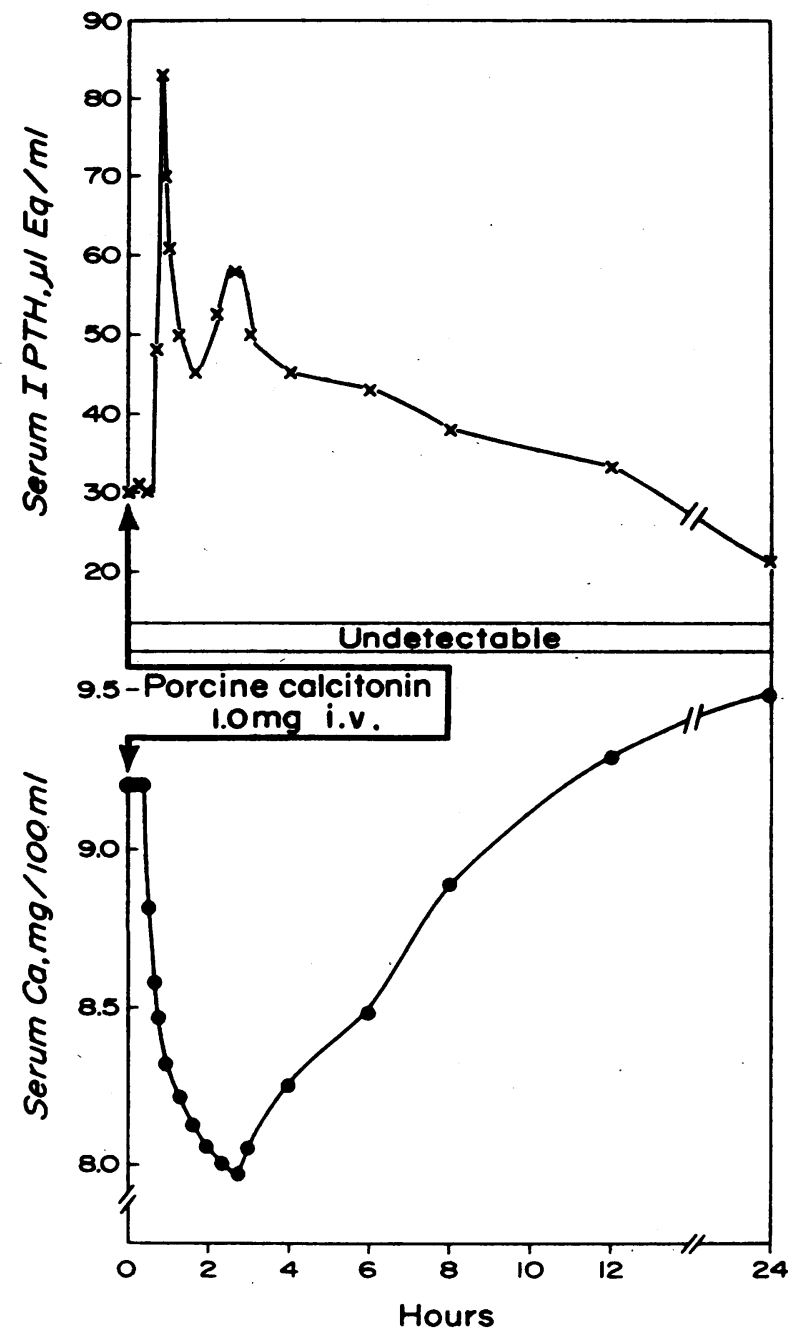

FIgure 11. Serum IPTH, in patient with Paget's disease of bone, in response to hypocalcemia produced by intravenous administration of $1 \mathrm{mg}$ of homogeneous porcine calcitonin. 
A plot of serum IPTH as a function of serum calcium in patients with proved primary hyperparathyroidism is shown in Fig. 13. There is a significant positive correlation between these variables, but the correlation coefficient $(r)$ is only $0.384(P<0.02)$. It is clear that moderately severe hypercalcemia (between 12.0 and 13.0 $\mathrm{mg} / 100 \mathrm{ml}$ ) may exist without concomitant increases in serum IPTH to greater than twice the value for the upper limit of normal (five patients) and, conversely, mild hypercalcemia (between 11.0 and $12.0 \mathrm{mg} / 100 \mathrm{ml}$ ) may exist associated with values for serum IPTH which are 3-10 times the upper limit of normal (five patients).

Fig. 14 shows values for serum IPTH plotted as a function of corresponding values for serum calcium for sera from normals, hypocalcemic patients, and patients with proved primary hyperparathyroidism and serum IPTH values less than $150 \mu \mathrm{lEq} / \mathrm{ml}$. There is a highly significant negative correlation between serum calcium and IPTH in the normal group. The serum IPTH is appropriately increased above the normal range in patients with hypocalcemia due to causes other than hypoparathyroidism or renal failure (that is, intestinal malabsorption or osteomalacia) (also see Fig. 12). Visual inspection of this plot shows complete discrimination between normal subjects and patients with primary hyperparathyroidism. A formal discriminant analysis of these data by the methods of Anderson and Bancroft (20) and Dixon (21) produced the expected separation, free of overlap (this is in marked contrast to the poor discrimination between these two groups obtained when only the serum IPTH was used).

Values for IPTH are uniformly increased from 3 to 100 times normal in patients with renal failure, as reported previously $(3,5,6)$. In other studies to be published, levels of IPTH are negatively correlated with creatinine clearance below $60 \mathrm{ml} / \mathrm{min}$ after renal transplantation.

\section{DISCUSSION}

Several special features of this radioimmunoassay system deserve discussion. We used ${ }^{181}$ I-labeled bPTH to compete with $\mathrm{hPTH}$ for binding to antibody to $\mathrm{pPTH}$ because our preparations of $\mathrm{pPTH}$ and $\mathrm{hPTH}$ were not suitable for ${ }^{181} \mathrm{I}$ labeling. Although unusual, there does not appear to be any objection, theoretical or otherwise, to this practice, especially because unlabeled bPTH and hPTH appear to react similarly in this system (Fig. 4).

The immune reaction between this anti-pPTH and ${ }^{121}$ I-labeled bPTH is inhibited to a small extent by serum proteins (Fig. 5) or some as yet unidentified factor in serum. We compensated for this phenomenon by assessing the degree of inhibition produced by quantities of hypoparathyroid serum matching those of unknowns and

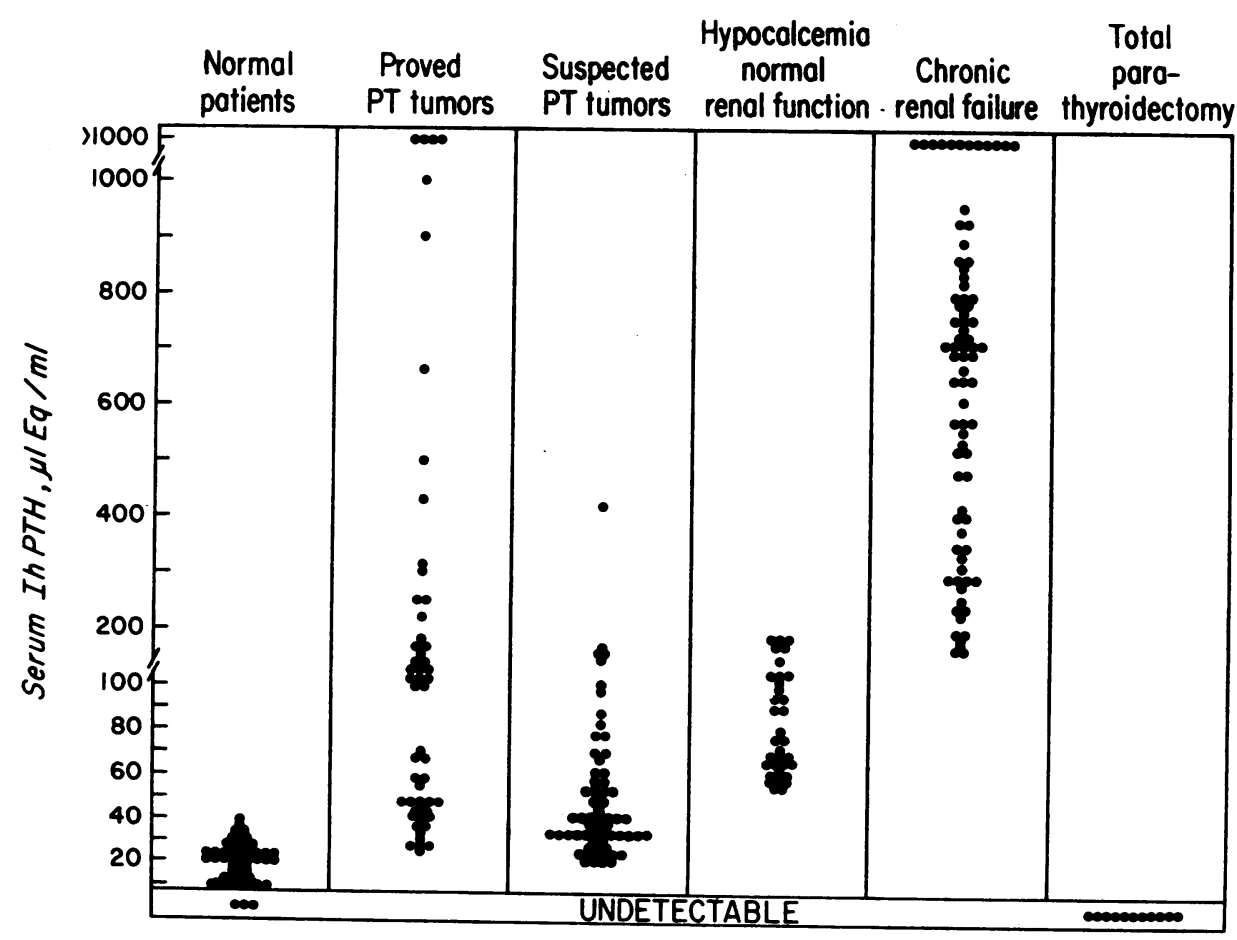

FIGURE 12 Serum IPTH in normal humans and patients with various disorders of parathyroid function. 
making necessary corrections (see Methods and Results). In practice this has not led to discernible misinterpretation of assay results because in most instances the great sensitivity of the assay allowed for the measurement of IPTH in multiple serum dilutions and the use of low concentrations of serum $(<10 \%)$. The influence of serum on the immune reaction with this antiserum is not unique; we have observed similar effects of serum with all antisera produced in our laboratory against porcine calcitonin and bPTH, even when species-specific ${ }^{181} \mathrm{I}-\mathrm{la}$ beled peptides were used.

The antiserum to $\mathrm{pPTH}$ used in the present immunoassay distinguishes between the immunoreactive species of $\mathrm{hPTH}$ in hyperparathyroid sera and that extracted and purified from parathyroid adenomata. A similar antiserum has been described by Berson and Yalow (2). They explained the phenomenon on the basis of immunochemical heterogeneity of PTH in serum. However, we found no essential immunologic differences in $\mathrm{hPTH}$ in the sera of patients with primary, secondary, or tertiary hyperparathyroidism or parathyroid cancer (Fig. 8). This suggests that the immunoreactive species of hPTH measured by the present immunoassay is the same in all hyperparathyroid sera and that, if immunoreactive fragments of hPTH in serum are being measured, their concentrations are relatively the same irrespective of renal functional status. The phenomenon cannot be explained on the basis of serum protein binding effects in vitro because it can be observed equally well whether or not extracted hormone is added to serum prior to its addition to the immunoassay system.

We recently have obtained evidence (22) that the extraction of serum in the same manner as that used for parathyroid adenomata (10) converts the serum hormone into a species which reacts, in the present immunoassay, similarly to adenoma-extracted hormone. This suggests that hormone extracted from the gland is immunochemically altered and that serum hormone may in fact be more representative of the native secreted species. We think that these observations not only justify but also require the use of the hPTH present in serum as a standard in the present immunoassay.

Comparison of the immunoreactivities of our preparations of bPTH (essentially homogeneous), pPTH (50\% pure), and G-100 hPTH (20\% pure) (Fig. 4) suggests that a conservative estimate of the sensitivity limit of the present immunoassay system is $0.1-0.2 \mathrm{ng} / \mathrm{ml}$ for hPTH. However, it is not reasonable to discuss the concentrations of hormone in serum in gravimetric terms because purified hPTH is unsuitable as a standard in this immunoassay. It is even possible that the antiserum used in these studies might have a higher affinity for the hormone species present in serum than for that extracted from adenomata. The fact that the immunoassay is

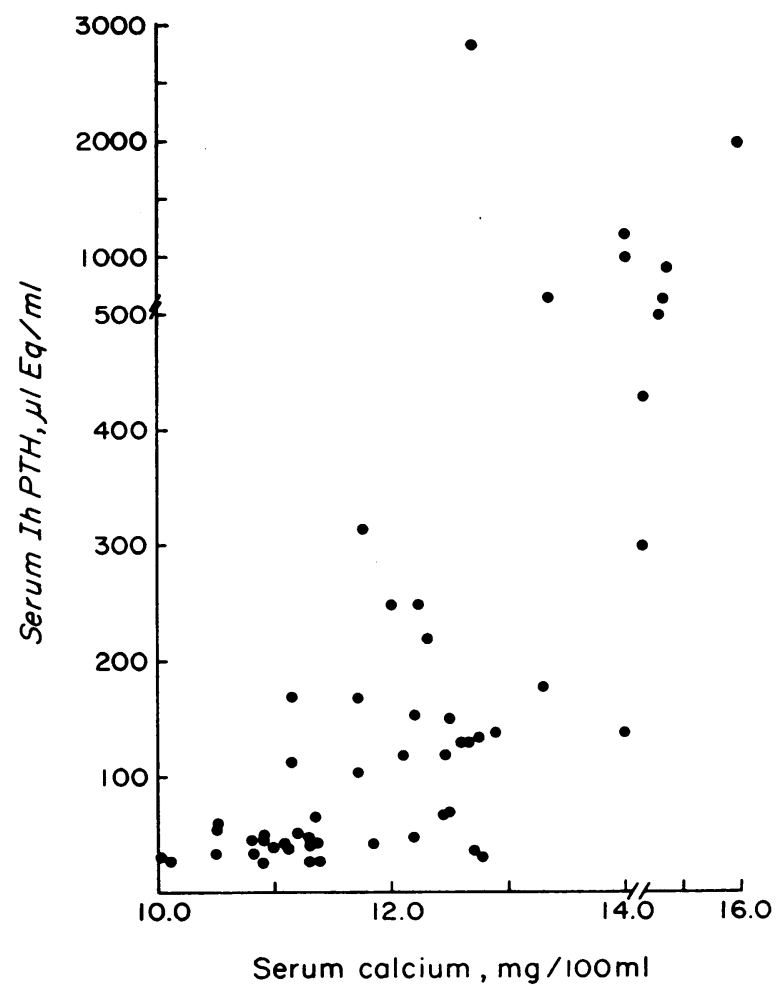

Figure 13 Serum IPTH as function of serum calcium in patients with surgically proved hyperparathyroidism.

capable of measuring the hormone present in $94 \%$ of the sera tested indicates that its sensitivity is greater than that of immunoassays of hPTH previously reported (5-7) except possibly for that of Reiss and associates $(1,3,4)$. Furthermore, studies of subjects with normal concentrations of IPTH, such as those shown in Figs. 9-11 and 14, lend strong support to the notion that the present immunoassay can quantitate, not merely detect, the hormone present in normal serum. At present we only can ascribe the apparent sensitivity of this immunoassay to a chance development of an antiserum to pPTH which has a high affinity for hPTH. We currently are immunizing a number of animals to pPTH in an attempt to determine if its cross-reaction with hPTH is better than that with bPTH.

Perhaps the most important criterion for the validity of any hormone assay is its ability to measure changes in hormone concentrations in the serum under conditions known to be associated with stimulation or suppression of the secretion of the hormone. In this regard, support for the present immunoassay is extensive. Induced hypercalcemia suppressed (Fig. 10) and hypocalcemia stimulated hormone secretion (Fig. 11). Serum calcium concentrations correlated negatively with those of serum IPTH over the normal serum calcium range (Fig. 14), as has been previously shown in cows (23), and hypo- 
calcemic subjects with disorders other than renal failure had appropriately increased concentrations of serum IPTH (Figs. 12 and 14). Serum IPTH was generally increased in patients with hyperparathyroidism (Fig. 12 ), and there was a positive correlation between the serum calcium and IPTH values in patients with the primary form of the disease (Fig. 13). The hormone was undetectable in the serum of patients with surgical hypoparathyroidism (Fig. 12).

Berson and Yalow (6) reported a large overlap in serum IPTH values between normal subjects and patients with proved primary hyperparathyroidism, whereas Reiss and associates $(3,4)$ indicated that, with their immunoassay, complete discrimination between these two groups was achieved. Our data are more in line with those of Berson and Yalow (6) except that we were able to measure the hormone in a greater percentage of normal subjects ( $94 \%$ vs. $80 \%$ ). More important, however, is that complete separation of normal subjects from patients with primary hyperparathyroidism could be achieved by evaluation, by formal discriminate analysis of the two variables, of both the serum IPTH as determined by our assay and the serum calcium (Fig. 14). The reasons for the discrepancy in results among these three assays are unclear but differences in sensitivity and specificity of the assays and time of serum sampling are reasonable considerations.

The demonstration of an almost twofold increase in serum IPTH during the late afternoon and evening in normal subjects (Fig. 9) might have been predicted on the basis of known diurnal variations in the urinary excretion of phosphorus (24-26) and of hydroxyproline (27). Although Berson and Yalow (28) did not show similar changes when they used another radioimmunoassay for hPTH, our observation, if found to be consistent, is of practical importance. It implies the need to sample serum at a time of day when levels of serum IPTH are likely to be lowest (probably between 8 and 10 a.m.) so that reasonable comparisons can be made. However, more information regarding this interesting phenomenon is required in both healthy and sick per-

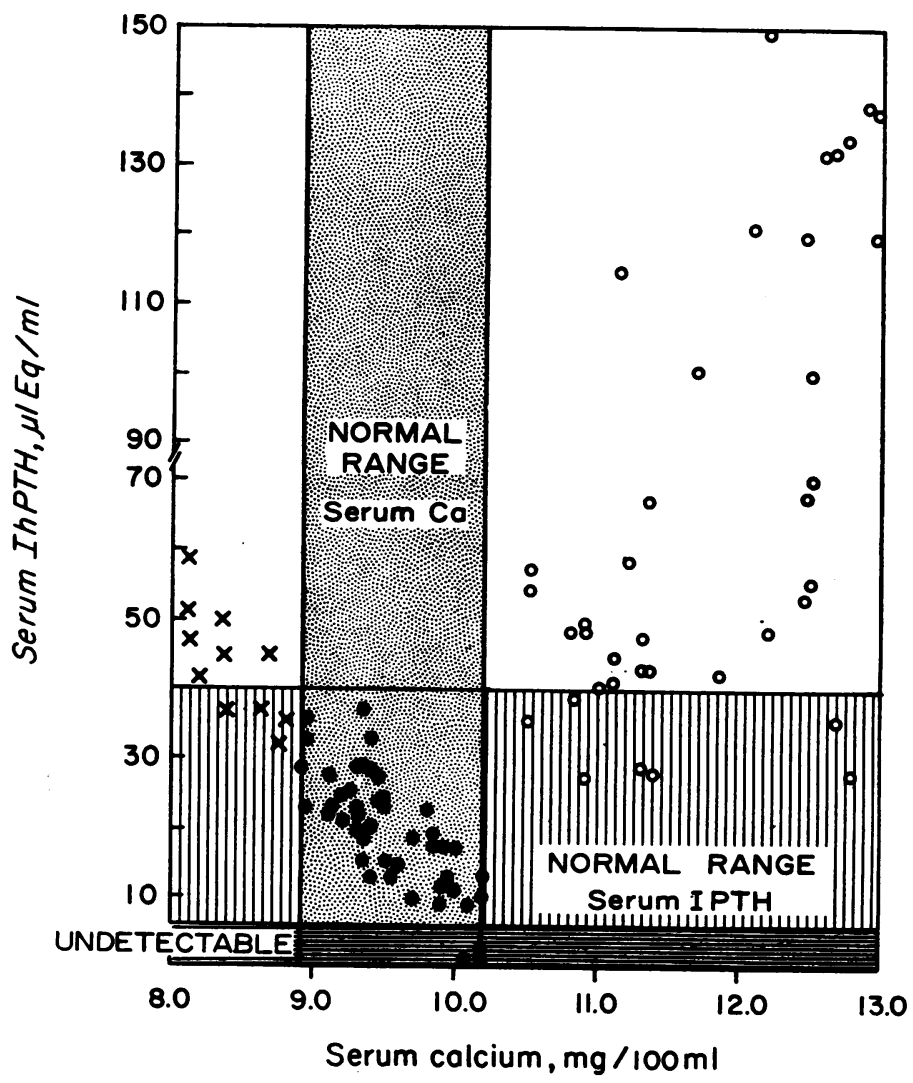

FIGURE 14 Serum IPTH as function of serum calcium in normals (๑), hypocalcemic patients (X) and patients with surgically proved primary hyperparathyroidism $(\mathrm{O})$ and serum IPTH values less than $150 \mu \mathrm{l} \mathrm{Eq} / \mathrm{ml}$ (correlation coefficient, $r$, for normals $=-0.569, P$ $<0.0001$ ) 
sons before reasonable assessment of its nature and importance is possible.

\section{ACKNOWLEDGMENTS}

We are indebted to numerous physicians at the Mayo Clinic for their generous cooperation, especially Doctors F. R. Keating, Jr., D. C. Purnell, D. A. Scholz, L. H. Smith, B. L. Riggs, R. S. Goldsmith, D. L. Hoffman, W. J. Johnson, A. Fournier, C. F. Anderson, and J. C. Hunt. Doctors E. H. Soule and L. B. Woolner kindly supplied us with parathyroid adenoma tissue.

This investigation was supported in part by Research Grant AM-12302 from the National Institutes of Health, U. S. Public Health Service.

\section{REFERENCES}

1. Reiss, E. 1968. Measurement of parathyroid hormone. Ann. Intern. Med. 69: 1325.

2. Berson, S. A., and R. S. Yalow. 1968. Immunochemical heterogeneity of parathyroid hormone in plasma. J. Clin. Endocrinol. Metab. 28: 1037.

3. Reiss, E., and J. M. Canterbury. 1968. A radioimmunoassay for parathyroid hormone in man. Proc. Soc. Exp. Biol. Med. 128: 501.

4. Reiss, E., J. M. Canterbury, and R. H. Egdahl. 1968. Experience with a radioimmunoassay of parathyroid hormone in human sera. Trans. Ass. Amer. Physicians Philadelphia. 81: 104.

5. Berson, S. A., R. S. Yalow, G. D. Aurbach, and J. T. Potts, Jr. 1963. Immunoassay of bovine and human parathyroid hormone. Proc. Nat. Acad. Sci. U. S. A. 49: 613.

6. Berson, S. A., and R. S. Yalow. 1966. Parathyroid hormone in plasma in adenomatous hyperparathyroidism uremia, and bronchogenic carcinoma. Science (Washington). 154: 907 .

7. Tashjian, A. H., Jr., A. G. Frantz, and J. B. Lee. 1966. Pseudohypoparathyroidism: assays of parathyroid hormone and thyrocalcitonin. Proc. Nat. Acad. Sci. U. S. A. 56: 1138 .

8. Littledike, E. T., and C. D. Hawker. 1967. Extraction, purification and partial characterization of porcine parathyroid hormone. Endocrinology. 81: 261.

9. Rasmussen, H., Y.-L. Sze, and R. Young. 1964. Further studies on the isolation and characterization of parathyroid polypeptides. J. Biol. Chem. 239: 2852.

10. Hawker, C. D., J. D. Glass, and H. Rasmussen. 1966. Further studies on the isolation and characterization of parathyroid polypeptides. Biochemistry. 5: 344.

11. Berson, S. A., and R. S. Yalow. 1966. Iodoinsulin used to determine specific activity of iodine-131. Science (Washington). 152: 205.
12. Hunter, W. M., and F. C. Greenwood. 1962. Preparation of iodine-131 labelled human growth hormone of high specific activity. Nature (London). 194: 495.

13. Yalow, R. S., and S. A. Berson. 1960. Immunoassay of endogenous plasma insulin in man. J. Clin. Invest. 39: 1157.

14. Snedecor, G. W., and W. G. Cochran. 1967. Statistical Methods. The Iowa State University Press, Ames. 6th edition. 593

15. Herbert, V., K.-S. Lau, C. W. Gottlieb, and S. J. Bleicher. 1965. Coated charcoal immunoassay of insulin. J. Clin. Endocrinol. Metab. 25: 1375.

16. Arnaud, C. D., and H. S. Tsao. 1969. Porcine calcitonin: simple procedure for isolation in high yield. Biochemistry. 8: 449.

17. Rosselin, G., R. Assan, R. S. Yalow, and S. A. Berson. 1966. Separation of antibody-bound and unbound peptide hormones labelled with iodine-131 by talcum powder and precipitated silica. Nature (London). 212: 355.

18. Berson, S. A., and R. S. Yalow. 1968. Radioimmunoassay of ACTH in plasma. J. Clin. Invest. 47: 2725.

19. Hoehn, J. G., O. H. Beahrs, and L. B. Woolner. 1969. Unusual surgical lesions of the parathyroid gland. Amer. J. Surg. 118: 770.

20. Anderson, R. L., and T. A. Bancroft. 1952. Statistical Theory in Research. McGraw-Hill Book Company, New York.

21. Dixon, W. J. 1967. BMD: Biomedical Computer Programs. University of California Press, Berkeley. 2nd edition. 185.

22. Arnaud, C. D., H. S. Tsao, and S. B. Oldham. 1970 Native human parathyroid hormone: an immunochemical investigation. Proc. Nat. Acad. Sci. U. S. A. 67: 415.

23. Sherwood, L. M., G. P. Mayer, C. F. Ramberg, Jr., D. S. Kronfeld, G. D. Aurbach, and J. T. Potts, Jr. 1968. Regulation of parathyroid hormone secretion: proportional control by calcium, lack of effect of phosphate. Endocrinology. 83: 1043

24. Fiske, C. H. 1921. Inorganic phosphate and acid excretion in the postabsorptive period. J. Biol. Chem. 49: 171.

25. Ollayos, R. W., and A. W. Winkler. 1943. Urinary excretion and serum concentration of inorganic phosphate in man. J. Clin. Invest. 22: 147.

26. Mills, J. N., and S. W. Stanbury. 1952. Persistent 24 hour renal excretory rhythm on a 12 -hour cycle of activity. J. Physiol. (London). 117: 22.

27. Mautalen, C. A., and C. Casco. 1970. Circadian rhythm of urinary total and free hydroxyproline excretion and its relation to creatinine excretion. J. Lab. Clin. Med. 75: 11 .

28. Berson, S. A., and R. S. Yalow. 1967. Radioimmunoassays of peptide hormones in plasma. $N$. Engl. J. Med. 277: 640 . 